\title{
FIBRINOLYSIS REGULATION BY PLATELETS RETAINING PLASMINOGEN AND TISSUE-TYPE PLASMINOGEN ACTIVATOR ON THEIR SURFACE
}

\author{
T. GRINENKO, O. YUSOVA, O. REVKA, I. PATALAKH, T. YATSENKO \\ Palladin Institute of Biochemistry, National Academy of Sciences of Ukraine, Kyiv; \\ e-mail: sedrickedel@gmail.com
}

Received: 22 July 2019; Accepted: 18 October 2019

\begin{abstract}
Platelets play a key role in hemostasis as cofactors of thrombin generation, fibrin polymerization centers, and initiators of clot retraction, while their ability to modulate clot dissolution remains less understood. The aim of this study was to investigate the interaction of plasminogen and tissue plasminogen activator with native and activated platelets, to determine the amount of plasmin generated by various activators in the presence of platelets, and the ability of platelets to modulate the rate of polymer fibrin hydrolysis. Spectrometric and immunofluorometric methods were used in the study. It was shown that intact circulating platelets carry a small amount of plasminogen on their surface, whereas thrombin-induced activation led to the exposure of plasminogen-binding sites on their plasma membrane. Activated platelets stimulated plasminogen activation by tissue plasminogen activator, urokinase, and streptokinase. Components of prothrombin complex enhanced plasminogen activation by tissue plasminogen activator on the surface of activated platelets. Model system with desAB-fibrin revealed the ability of platelets to stimulate fibrinolysis. These results suggest that the regulation of fibrinolysis by platelets is provided by the binding of plasminogen and plasminogen activators on their surface, acceleration of plasmin generation and, consequently, acceleration of the onset of fibrin lysis and reducing of the clot lifetime, which is important to maintain hemostatic balance.
\end{abstract}

Keywords: platelets, plasminogen, tissue plasminogen activator (t-PA), urokinase, streptokinase, prothrombin complex.

$\mathrm{P}$ latelets play a key role in normal hemostasis and pathological thrombi formation. Due to their ability to secrete a wide range of biologically active substances, platelets are involved in numerous (patho)physiological processes, e.g. blood vessels recovery, angiogenesis, inflammation, oncogenesis, immune response, etc.

Heterogeneity is one of platelets peculiarities. Platelets activation results in the formation of two subpopulations with different functional features. Pro-aggregatory platelets express activated $\alpha \operatorname{IIb} \beta 3$, bind fibrinogen and other platelets and thus strengthen the clot and preserve it from premature dissolution. Procoagulant platelets expose phosphatidylserine, which binds coagulation factors, thereby enhancing thrombin formation (EC 3.4.21.5) and polymer fibrin formation $[1,2]$.
The ability of platelets to modulate clot dissolution has been less studied. Until recently, platelets were believed to demonstrate mostly antifibrinolytic properties due to the high concentration of fibrinolysis inhibitors (PAI-1, TAFI) in alpha granules [3-6]. Now, it has been found that platelets are involved in both the formation of fibrin and its dissolution $[7,8]$.

Dissolution of fibrin clots is carried out by the proteolytic enzyme plasmin (EC 3.4.21.7), which is formed from inactive plasminogen by activators. Tissue-type plasminogen activator (t-PA) (EC 3.4.21.68) mainly activates the proenzyme on the surface of fibrin clots [9], whereas urokinase (uPA) (EC 3.4.21.73) mainly activates it on the surface of various cells $[10,11]$. Plasmin and activators associated with fibrin or cell membrane are protected against inhibition by alpha-2-antiplasmin and a first-

(C) 2019 Grinenko T. et al. This is an open-access article distributed under the terms of the Creative Commons Attribution License, which permits unrestricted use, distribution, and reproduction in any medium, provided the original author and source are credited. 
type plasminogen activator inhibitor (PAI-1), respectively.

Platelets present binding sites for fibrinolytic proteins on the outer membrane. Plasminogen binds to platelets by two mechanisms: $\alpha \operatorname{IIb} \beta 3$ - and fibrindependent and independent [12]. The latter involves the interaction of plasminogen with membrane-associated proteins exposed during activation, such as actin [13], thrombospondin [14], and proteins having C-terminal lysine residues [15].

t-PA binding to the surface of inactivated platelets is reversible, concentration-dependent, mediated by one class of low affinity sites, enhanced by thrombin stimulation, and partially replaced by plasminogen [16]; single-chain urokinase-type plasminogen activator (scu-PA) is detected on membranes of unstimulated platelets in low concentrations (1.3 ng per $10^{9}$ platelets) [17]. Despite the existing evidence about the association of t-PA and scu-PA with the membranes of intact and activated platelets, receptors responsible for the binding of these activators remain unknown. The ability of platelets to accumulate proteins of plasminogen activation system on their surface indicates the possible involvement of these cells in the localization and regulation of the fibrinolytic process.

The aim of this study was to investigate the interaction of plasminogen and tissue plasminogen activator with intact and activated platelets, to determine the amount of plasmin generated by various plasminogen activators in the presence of platelets, and their ability to modulate the rate of polymer fibrin hydrolysis.

\section{Materials and Methods}

Plasminogen preparation. Glu-plasminogen was purified from donor citrate plasma as described in [7], the purity was assessed using low-pH polyacrylamide gel electrophoresis [8]. Glu-plasminogen conjugation with FITC (Sigma-Aldrich, USA) was carried out using the manufacturer's protocol.

Platelet isolation. Human blood platelets were obtained from whole blood of healthy, drug-free individuals. Blood was collected in $0.1 \mathrm{M}$ sodium citrate, 0.08 $\mathrm{M}$ citric acid, 0.11 $\mathrm{M}$ glucose in 9:1 ratio. Differential centrifugation was used to collect platelets as described [9]. The amount of cells and their viability were assessed using aggregometer (SOLAR AT-02, Belorussia). Platelets suspension was stored at $37^{\circ} \mathrm{C}$ up to $3 \mathrm{~h}$.

Prothrombin complex preparation. Prothrombin complex was obtained from donor citrate plasma using adsorption on barium sulfate. The precipitate was suspended for $1 \mathrm{~h}$ at $4{ }^{\circ} \mathrm{C}$ in $0.05 \mathrm{M}$ tris buffer $\mathrm{pH} 7.4$ with $0.2 \mathrm{M} \mathrm{NaCl}, 0.01 \mathrm{M}$ benzamidine and $0.02 \mathrm{M}$ EDTA. The suspension was centrifuged for $20 \mathrm{~min}$ at $2500 \mathrm{rpm}$ and $4{ }^{\circ} \mathrm{C}$. The supernatant was aliquoted and stored at $-20^{\circ} \mathrm{C}$. Every portion of protein solution before using was thawed at $37{ }^{\circ} \mathrm{C}$ and passed through PD-10 column, equilibrated with $0.05 \mathrm{M}$ Tris buffer $\mathrm{pH} 7.4$ with $0.13 \mathrm{M} \mathrm{NaCl}$, for benzamidine and EDTA elimination. Proteins concentration in the samples was assessed using $280 \mathrm{~nm}$ and $320 \mathrm{~nm}$ light absorbance and calculated using 14.0 extinction coefficient $\left(\mathrm{E}_{1 \%}{ }^{280 \mathrm{~nm}}\right)$.

Rabbit polyclonal anti-t-PA antibodies preparation. Animals were immunized using human recombinant tissue-type plasminogen activator (Actilyse, Boehringer Ingelheim, Germany) as described elsewhere [21]. Anti-t-PA immunoglobulins G were purified using affinity chromatography successively on protein A-sepharose and t-PA-sepharose. The antibodies were stored in $25 \%$ glycerol at $-20{ }^{\circ} \mathrm{C}$.

Plasminogen activation assay. Effect of prothrombin complex on Glu-plasminogen activation by tissue type plasminogen activator in the presence of resting and activated platelets was assessed as plasmin formation using $\mathrm{S}_{2251}$ chromogenic substrate for plasmin. Before the reaction platelets were activated with 0.25 NIH thrombin (Sigma Aldrich, USA) in microtitration plates for $5 \mathrm{~min}$ at room temperature, then incubated with prothrombin complex $(100 \mu \mathrm{g})$ for $5 \mathrm{~min}$. Control group of cells was incubated only with prothrombin complex. Reaction medium $(0.25 \mathrm{ml})$ contained platelets ( $10^{7}$ cells), gluplasminogen $(0.25 \mu \mathrm{M})$, t-PA (5 IU), $\mathrm{S}_{2251}(0.3 \mathrm{mM})$ and $50 \mathrm{mM}$ Tris buffered saline with $1 \mathrm{mM} \mathrm{CaCl}_{2}$ $\mathrm{pH}$ 7.2. Plasmin activity was assessed as change of the medium light absorption at $405 \mathrm{~nm}$ using Multiscan Titertek plate reader (Multiskan, Finland).

Flow cytometry. Interaction of FITC-plasminogen with resting and activated platelets was measured with flow cytometry on COULTER EPICS XL (Beckman Coulter, USA). Washed platelets $\left(10^{8}\right.$ cells $\left./ \mathrm{ml}\right)$ were activated with $2 \mathrm{NIH} / \mathrm{ml}$ thrombin (Sigma, USA) for $5 \mathrm{~min}$ at $37{ }^{\circ} \mathrm{C}$ and as result at least $90 \%$ of the cells were activated. After the activation platelets were washed in $20 \mathrm{mM}$ HEPES buffer, containing $137 \mathrm{mM} \mathrm{NaCl}, 4 \mathrm{mM}$ $\mathrm{KCl}, 0.2 \mathrm{mM} \mathrm{MgCl}_{2}, \mathrm{pH} 7.4$ (HEPES buffer), and then resuspended in $0.05 \mathrm{M}$ sodium-phosphate buffer with $0.15 \mathrm{M} \mathrm{NaCl}$ and $1 \% \mathrm{BSA}, \mathrm{pH} 7.4$ (working buffer). Intact cells underwent the same procedure 
but without thrombin addition. Washed intact and activated cells were incubated with FITC-conjugated plasminogen $(1 \mu \mathrm{M})$ for $30 \mathrm{~min}$ at $37{ }^{\circ} \mathrm{C}$ in the dark and then twice washed using working buffer. For the analysis of labeled plasminogen interaction with platelets were used samples containing 10000 cells. Fluorescence excitation wavelength was $488 \mathrm{~nm}$, cells fluorescence intensity was measured at 515$535 \mathrm{~nm}$ (FL1 channel). The level of control cells fluorescence (intact cells non-incubated with FITCplasminogen) was taken as 100\%. "FCS Express V3" software (DeNovo Software, USA) was used for the data analysis.

Interaction of FITC-conjugated streptokinase with platelets was investigated using flow cytometry as described for FITC-conjugated plasminogen. Intact and thrombin-activated cells were incubated with FITC-conjugated streptokinase in the presence of Glu-plasminogen $(1 \mu \mathrm{M})$ or without the proenzyme.

Fluorescent spectroscopy. Interaction of t-PA with platelets was investigated using rabbit polyclonal anti-t-PA antibodies and secondary FITC-conjugated anti-rabbit antibodies (Sigma Aldrich, USA). Samples of washed intact platelets $\left(10^{8}\right.$ cells in 0.3 $\mathrm{ml}$ HEPES buffer) were incubated with anti-t-PA antibodies $(10 \mu \mathrm{g})$ at $37{ }^{\circ} \mathrm{C}$ for $60 \mathrm{~min}$ and then washed twice in HEPES buffer by centrifugation $(15 \mathrm{~min}$, $200 \mathrm{~g}$ ). Washed cells were resuspended in $0.3 \mathrm{ml}$ of HEPES buffer and incubated with secondary antirabbit FITC-conjugated antibodies for $40 \mathrm{~min}$ in the dark at $37{ }^{\circ} \mathrm{C}$, washed twice, resuspended in $1 \mathrm{ml}$ of $50 \mathrm{mM}$ tris buffer with $130 \mathrm{mM} \mathrm{NaCl}, \mathrm{pH} 7.4$, and analyzed. Fluorescence of the cells was measured using spectrofluorometer QuantaMaster TM 40 (PTI Inc., Canada) at $37{ }^{\circ} \mathrm{C}$ and stirring. FITC fluorescence spectra were registered in the 500-600 nm range with $1 \mathrm{~nm}$ step. Excitation wavelength was $490 \mathrm{~nm}$. Obtained results were analyzed using Origin Lab 9 software (OriginLab Corp., USA).

Turbidimetry. Platelets effect on desAB fibrin lysis was investigated by change of clot turbidity using spectrophotometer SF-26 (LOMO, USSR) with thermostatic cuvette. Reaction medium $(1 \mathrm{ml})$ contained $50 \mathrm{mM}$ Tris buffer with $1 \mathrm{mM} \mathrm{CaCl}, \mathrm{pH} 7.4$, $15 \mu \mathrm{g} / \mathrm{ml}$ Glu-plasminogen, $5 \mathrm{IU} / \mathrm{ml} \mathrm{t-PA,} 5 \cdot 10^{7}$ cells/ $\mathrm{ml}$ platelets suspension, and $1 \mathrm{NIH} / \mathrm{ml}$ thrombin. After 5 min preincubation of the reaction medium at $37{ }^{\circ} \mathrm{C}$ for platelets activation, $200 \mu \mathrm{g} / \mathrm{ml}$ of desAB fibrin was added. Registration of clot density was started at the moment of desAB fibrin addition and polymerization start. Obtained kinetic curves were assessed and overall clot lifetime, time of lysis start, half-lysis time and area under the curve were calculated. Statistical analysis of the results was performed using MS Office Excel 2016 software.

\section{Results and Discussion}

It has been shown that radiolabelled plasminogen ( ${ }^{125} \mathrm{I}-$ Glu-plasminogen) specifically binds to human washed platelets. $K_{\mathrm{d}}$ for thrombin-stimulated platelets is $2.6 \pm 1.3 \mu \mathrm{M}$, and the amount of bound plasminogen is up to $(190 \pm 44) \cdot 10^{3}$ molecules per cell, while unstimulated platelets bind (37 \pm 15$) \cdot 10^{3}$ molecules per cell with $K_{\mathrm{d}} 1.9 \pm 0,15 \mu \mathrm{M}$ [24]. Our aim was to determine the level of plasminogen/ plasmin, associated with the surface of native and thrombin-activated platelets, using methods of flow cytometry and determination of enzymatic activity.

The ability of platelets to bind and activate plasminogen on their surface was evaluated by the amidolytic activity of plasmin in the presence of washed native or thrombin-activated platelets with or without addition of t-PA or Glu-plasminogen in combination with t-PA. Platelets were activated in the incubation medium with the addition of $1 \mathrm{NIH}$ thrombin. t-PA-dependent activation of plasminogen did not occur in solution: in samples containing zymogen and its activator in the absence of platelets, amidolytic activity was absent during the whole time

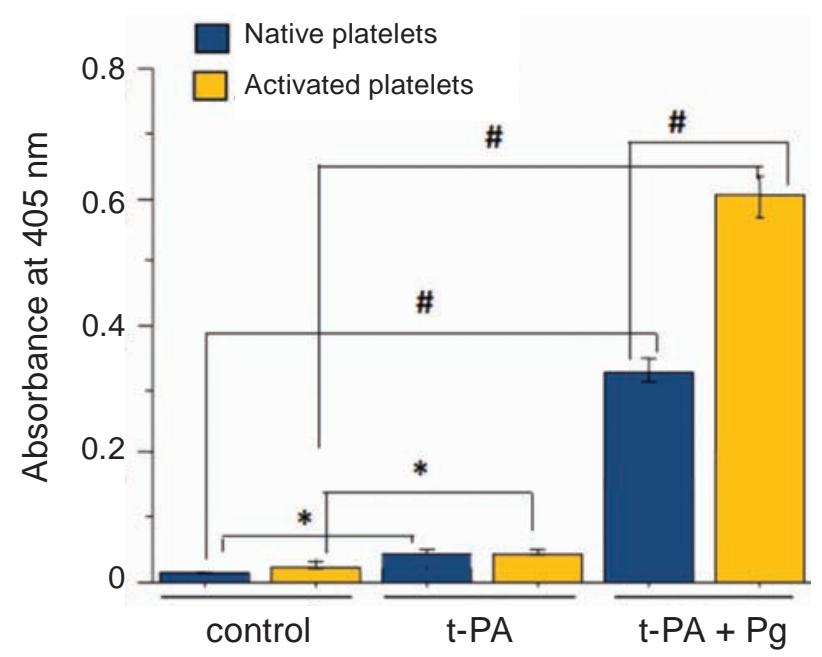

Fig. 1. Amidolytic activity of plasminogen/plasmin, associated with the surface of intact and activated platelets without and in the presence of tissue plasminogen activator or tissue plasminogen activator and plasminogen. ${ }^{*} P \leq 0.05 ;{ }^{*} P \leq 0.01$ 
of observation. In the medium containing only intact or activated platelets, in the absence of plasminogen and tissue plasminogen activator, after $60 \mathrm{~min}$ of incubation, residual amidolytic activity of plasmin was observed, which may be a result of activation by endogenous activators of plasminogen, bounded to the surface of circulating platelets. Notably, with the addition of tissue plasminogen activator, a slight increase in the level of p-nitroaniline occurred, which was similar in the presence of both native and activated platelets. These results show that platelets obtained by centrifugation carry a small amount of plasminogen on their surface. Thus, circulating native platelets are able to bind a very small amount of plasminogen. A similar level of amidolytic activity indicates that platelets, activated by thrombin, do not secrete additional amounts of plasminogen. At the same time, amidolytic activity increased dramatically when both plasminogen and tissue plasminogen activator are added to intact and activated cells. Moreover, the level of activity in the presence of thrombin-induced platelets was almost 2 times higher comparing to that in the presence of intact cells, which indicates the exposure of additional plasminogen-binding sites on the platelets surface after agonist-induced activation. The increase of amidolytic activity in the presence of intact platelets, plasminogen and tissue plasminogen activator can be explained by the partial activation of platelets during centrifugation.

Plasminogen binding to platelets, evaluated by the change in amidolytic activity with different concentrations of proenzyme, was a dose-dependent process (Fig. 2). With the increase of zymogen amount in the reaction medium, saturation of plasminogen binding sites on the plasma membrane of native and thrombin-activated cells occurred at 0.5 and $0.1 \mu \mathrm{M}$ concentrations, respectively.

Fig. 3 represents determination of the level of FITC-plasminogen bound to the surface of intact and activated platelets, using flow cytometry method. Due to the fluorescence intensity of the control (intact platelets not incubated with Glu-plasminogen), a gate separating non-fluorescent cells was determined (Fig. 3, A). Incubation of the native cells with FITCplasminogen resulted in a $67 \%$ increase in the number of events with a fluorescence signal. The fluorescence intensity was increased by $300 \%$, which indicates the sorption of FITC-labeled plasminogen on the surface of intact platelets (Fig. 3, B). In the presence of thrombin-activated cells, an increase in

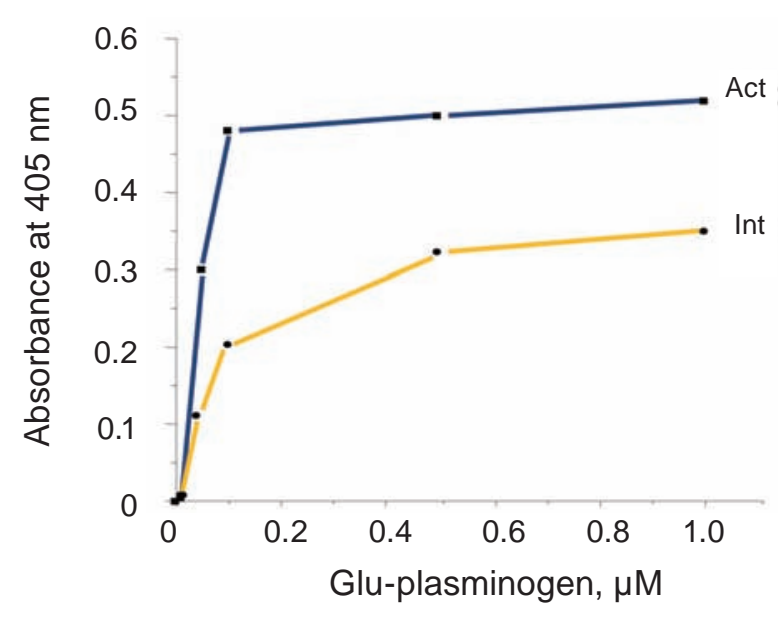

Fig. 2. Glu-plasminogen binding to intact and activated platelets depending on proenzyme concentration

the number of FITC-plasminogen-positive cells was significantly higher (75\%), whereas the fluorescence intensity increased by $650 \%$ (Fig. 3, B).

To summarize, using flow cytometry and enzymatic activity assay, we found that isolated activated platelets bind twice as much plasminogen on their surface than intact cells. It was shown that circulating platelets carry a small amount of plasminogen on their surface, whereas thrombin-induced activation leads to exposure of plasminogen-binding sites on their plasma membrane.

According to the literature, radiolabeled $\left({ }^{125} \mathrm{I}\right)$ recombinant tissue plasminogen activator (rt-PA) interacts with inactive and thrombin-stimulated platelets, with $K_{\mathrm{d}} 340 \pm 25$, and $800 \pm 60 \mathrm{nM}$, respectively [16]. Our next task was to investigate if tissue plasminogen activator is present on the surface of platelets isolated from donor blood. Presence of tissue plasminogen activator was detected by spectrofluorimetry using tissue plasminogen activator antibodies and secondary FITC-conjugated antibodies. Studies were performed on platelets obtained from blood samples from four different donors (Fig. 4).

Platelets incubated with secondary antibodies were taken as a control. The intensity of fluorescence in the analyzed and control samples was 5-12 times different, indicating the binding of t-PA antibody to its antigen on the cells' surface. The difference in the intensity signal between individual samples is explained by the individual characteristics of the donors. Thus, tissue plasminogen activator was detected by the t-PA antibodies on the plasma membrane of isolated native platelets, indicating the presence of 

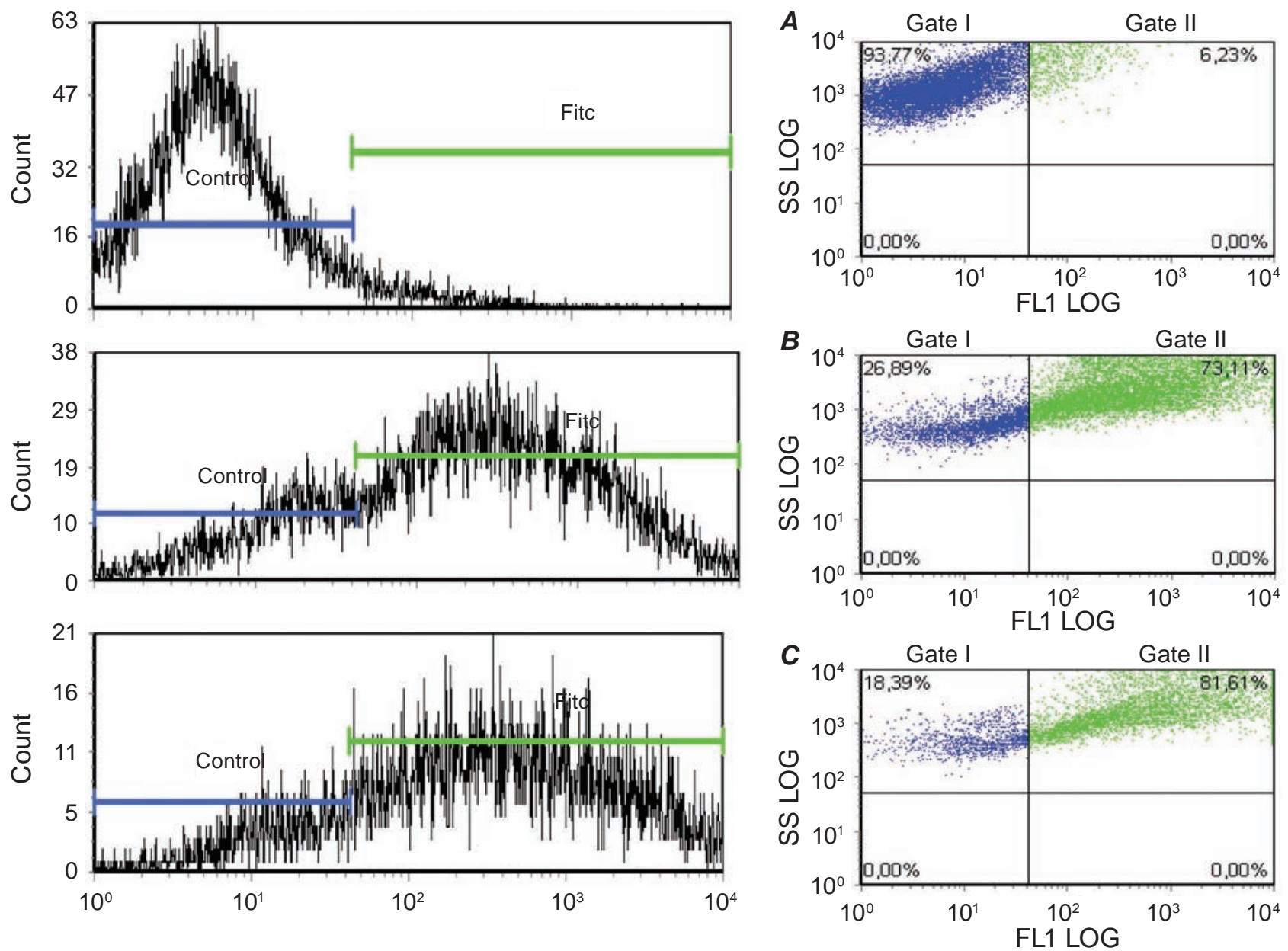

Fig. 3. Fluorescence histograms and dot plots of platelets distribution: intact platelets (A), intact platelets with FITC-plasminogen (B); thrombin-activated platelets with FITC-plasminogen (C)

specific binding sites for this protein on the surface of the circulating platelets in the bloodstream.

Effective activation of receptor-bound plasminogen requires localization of its activator on the same cell surface. Literature data about the role of platelets as a cofactor in the process of plasminogen activation by its various activators, namely tissue plasminogen activator, urokinase and streptokinase, are controversial. According to results obtained by PAGE electrophoresis, plasmin is detected on platelet membranes during activation by all types of activators [24]. Chromogenic substrate assay showed the effect of platelets on the formation of plasmin after plasminogen activation by tissue plasminogen activator but not urokinase or streptokinase [25], whereas in other studies, urokinase activated platelets-bound plasminogen $[26,7]$.

Platelets' $\left(1 \cdot 10^{7}\right.$ cells) impact on Glu-plasminogen activation by tissue activator, urokinase, and streptokinase was studied with $250 \mathrm{nM}$ of Glu-plas- minogen, a concentration at which saturation of the plasminogen binding sites on platelet membranes is reached. To compare the effectiveness of different activators, the reaction was performed at the same molar ratio of each of the activator to zymogen (1: 200). The kinetic curves of the plasminogen activation by all types of activators without and in the presence of activated platelets are presented in Fig. 5, $A, B$.

Activated platelets most effectively stimulated activation of plasminogen by streptokinase and showed a weaker, almost identical effect on activation by urokinase and tissue plasminogen activator. Based on the obtained kinetic curves, the amount of plasmin formed without and in the presence of cells was calculated (Fig. 6). The amount of enzyme was determined by optical density change on a linear region of the kinetic curve and was calculated using the formula $(\Delta \mathrm{E} 405: \Delta \mathrm{t}) / 0.002$, where 0.002 - experimentally determined absorption of p-nitroaniline released during hydrolysis of chromogenic substrate 


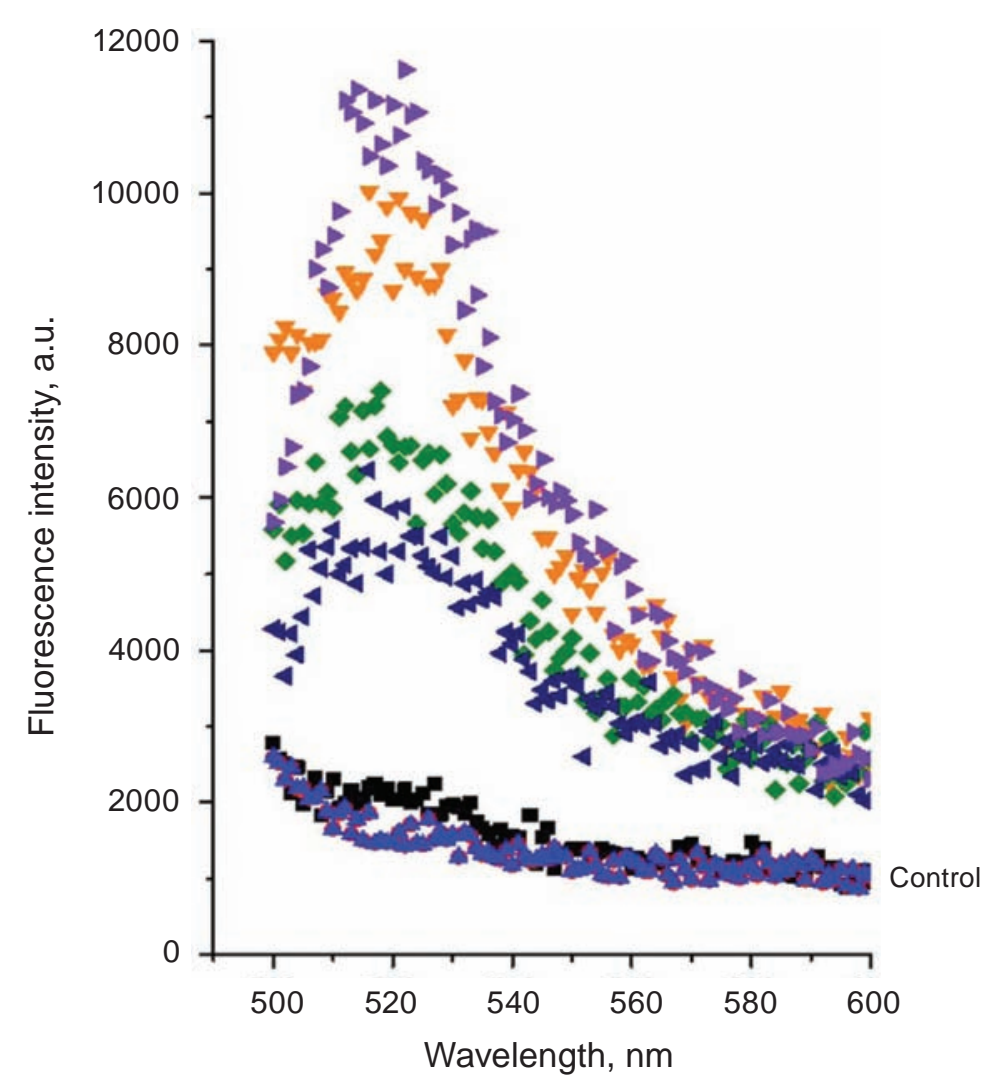

Fig. 4. Detection of tissue plasminogen activator on the surface of intact platelets using rabbit anti-t-PA antibodies and secondary FITC-labeled anti-rabbit antibodies. Fluorescence spectrum of platelets without t-PA antibodies is shown as a control. Platelets were obtained from 4 donors
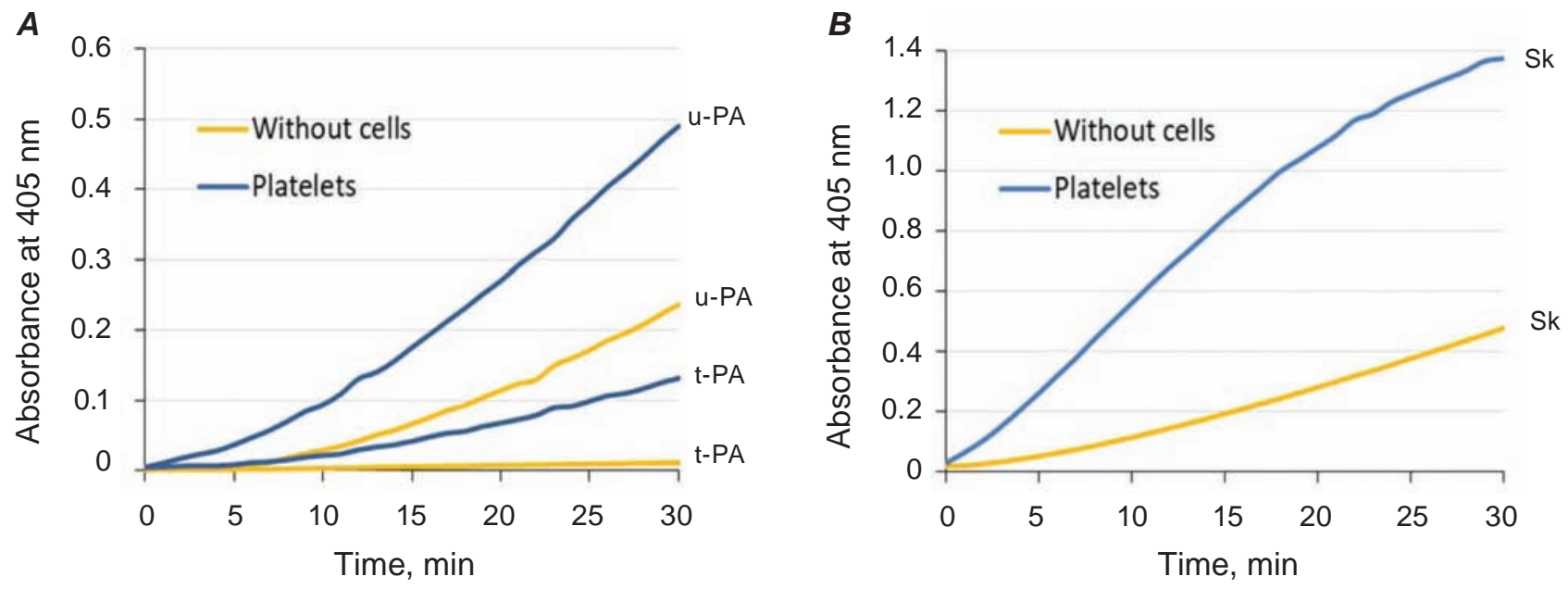

Fig. 5. A. Kinetics of Glu-plasminogen activation by tissue plasminogen activator ( $P A)$ and urokinase (u-PA) without and in the presence of thrombin-stimulated platelets. B. Kinetics of Glu-plasminogen activation by streptokinase (Sk) without and in the presence of thrombin-stimulated platelets

by $1 \mathrm{nM}$ of plasmin in $1 \mathrm{~min}$. The data presented in Fig. 6 indicate that in the presence of platelets ( $4 \cdot 10^{7}$ cells $/ \mathrm{ml}$ ) by activation of $250 \mathrm{nM}$ of plasminogen, 25.8, 8.3, and $5.4 \mathrm{nM}$ of plasmin is produced by streptokinase, urokinase, and tissue plasminogen activator, respectively.

This stimulating effect of platelets can be explained by the increase of the local concentration of 


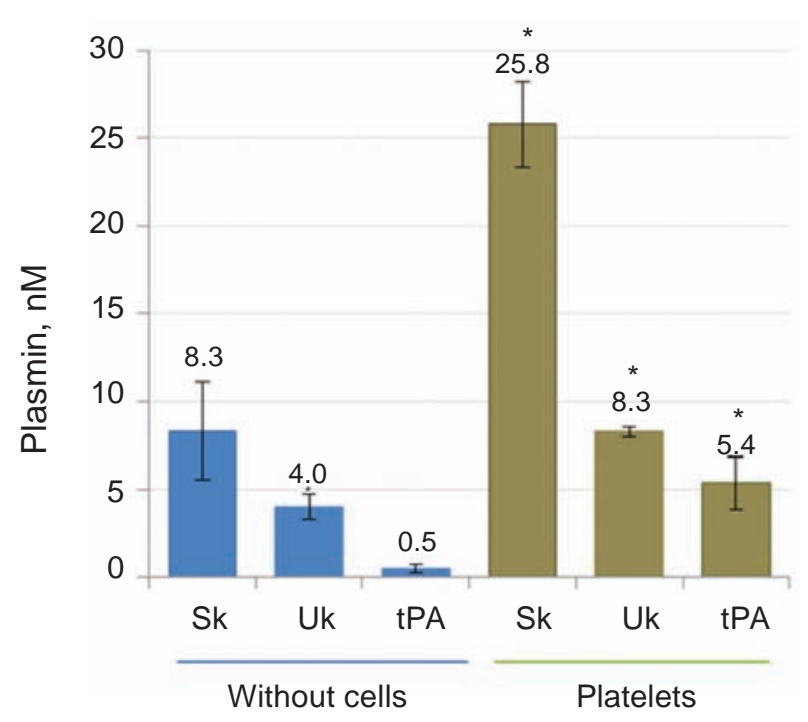

Fig. 6. Amount of plasmin generated during activation of 250 nM Glu-plasminogen by streptokinase, urokinase and tissue plasminogen activator with 1:200 molar ratio of activator:zymogen, without and in the presence of platelets. ${ }^{*} P \leq 0.05$

plasminogen and its activators on the cell surface and transformation of bound Glu-plasminogen to the open conformation. No data is available about the interaction of streptokinase with platelets, so we also studied plasminogen-dependent and plasminogen-independent binding of streptokinase to intact and activated cells. The studies were performed with FITC-labeled streptokinase using flow cytometry method. Fig. 7 represents typical graphs of fluores-

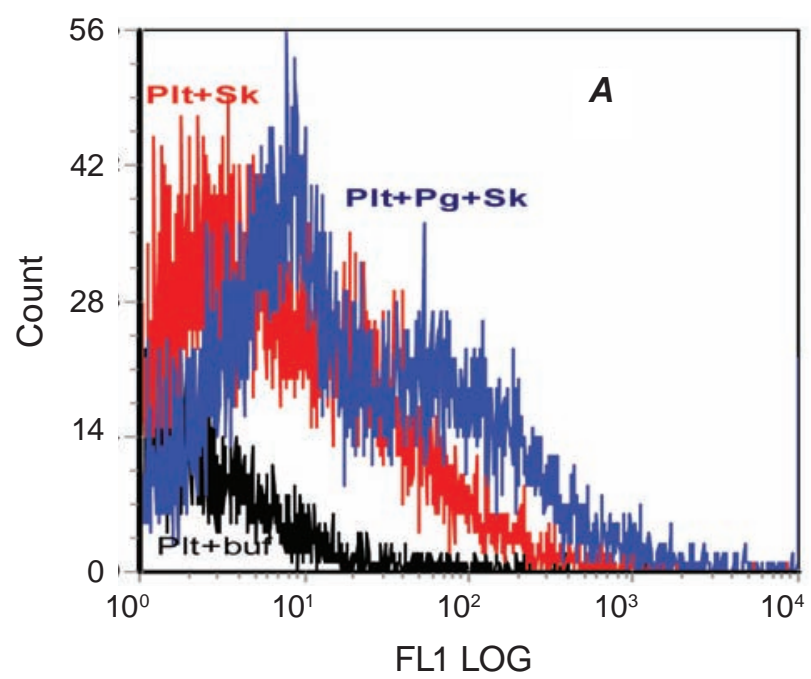

cence intensity of platelets, incubated with streptokinase and additionally with Glu-plasminogen. The fluorescence intensity of intact and thrombin-activated platelets was taken as $100 \%$. In the presence of streptokinase, the intensity of intact cells signal increased by 3 times, while the signal of activated cells - by 26 times. Preincubation of cells with Gluplasminogen led to a significant increase in the fluorescence signal of intact and activated platelets - by 26 and 40 times, respectively.

Obtained results indicate that exogenous plasminogen activator - streptokinase - is absorbed on the plasma membrane of intact and thrombinactivated platelets in a plasminogen-dependent and plasminogen-independent manner. Considering a relatively high level of plasmin produced on the platelet surface by streptokinase, obtained data may be useful during selection of treatment strategy for patients infected with $\beta$-hemolytic streptococci and during thrombolytic therapy by streptokinase.

According to current concept, plasminogen binds predominantly to phosphatidylserine-exposing procoagulant platelets [8], which also accumulate tenase and prothrombinase complexes responsible for the formation of FXa and thrombin, respectively. Of particular interest are the data that coagulation proteins, namely FXa, can also act as a plasminogen receptor. Autoproteolysis or plasmin processing of FXa has been shown to expose C-terminal lysine residues, resulting in the ability of procoagulant enzyme to act also during plasminogen activation by tissue plasminogen activator $[27,28]$ and to accelera-

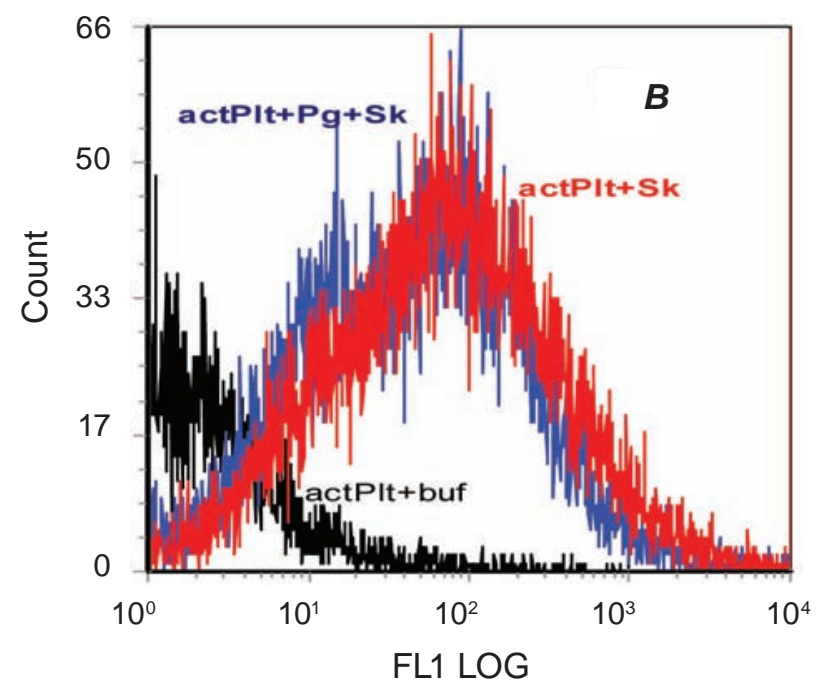

Fig. 7. Fluorescence of intact (A) and agonist-activated (B) platelets with FITC-labeled streptokinase without and in the presence of Glu-plasminogen 
te fibrinolysis $[29,30]$. Therefore, we isolated the proteins of the prothrombin complex from human blood plasma by using barium sulfate and extraction with EDTA solution and examined their ability to influence the generation of plasmin on platelets surface. It can be seen (Fig. 8) that the prothrombin complex does not affect the plasminogen activation process on the surface of intact platelets and more than two times elevate the level of activation in the presence of thrombin-stimulated platelets. These results indicate that components of the prothrombin complex bound to the surface of activated platelets may be involved in the interaction of plasminogen activation system proteins with platelets, but the mechanism of this impact requires further investigation.

A model system using desAB-fibrin allows to test the effect of platelets directly on the fibrinolysis process separately from the coagulation cascade. We used the physiological ratio of platelets, desAB-fibrin and plasminogen concentrations, as well as t-PA concentration, to evaluate the effect of platelets on fibrinolysis. Figure 9 shows typical curves of desAB fibrin formation and hydrolysis under the mentioned experimental conditions.

The curves were compared using the following parameters: clot lifetime (time to fully complete polymer fibrin lysis); time of the beginning of the lysis; half-lysis time (i.e. time during which the clot absorption value is reduced twice comparing to the maximum absorption); maximum lysis rate (defined as a tangent); area under the curve (calculated as a definite integral). Platelets significantly reduced the half-lysis time (from $30.33 \pm 4.7$ to $23.33 \pm 0.47 \mathrm{~min}$ ) and clot lifetime (from $38.33 \pm 2.36$ to $31.6 \pm 2.36 \mathrm{~min}$ ) with a corresponding decrease in the area under the coagulation/lysis curve by $17 \%$ (4.25 \pm 0.75 OD unit $\mathrm{min}^{-1}$ in the presence of platelets compared with $5.02 \pm 0.7$ for control), which together indicates stimulation of fibrinolysis by platelets. It should also be noted that in the presence of platelets, fibrin polymerization was accompanied by an additional increase in the optical density of the clot (compared to the cell-free control) due to its retraction (Fig. 9, control curves). Thus, cell-free and platelet-containing clots were different in structure and density of the polymer network, which created different "starting conditions" for lysis. Taking into consideration this difference, the ratio of the area under the hydrolysis curve of desAB-fibrin to the area under its polymerization curve was compared. It was 0.64 for control clots and 0.49 for plateletscontaining clots. Therefore, in our conditions, the efficiency of fibrin clot dissolution was increased by $30 \%$ in the presence of platelets. It can be concluded that the acceleration of desAB-fibrin hydrolysis in the presence of platelets was mostly due to their predominant effect on the activation of plasminogen by tissue plasminogen activator. This is evidenced, in particular, by platelet-induced reduction of lysis

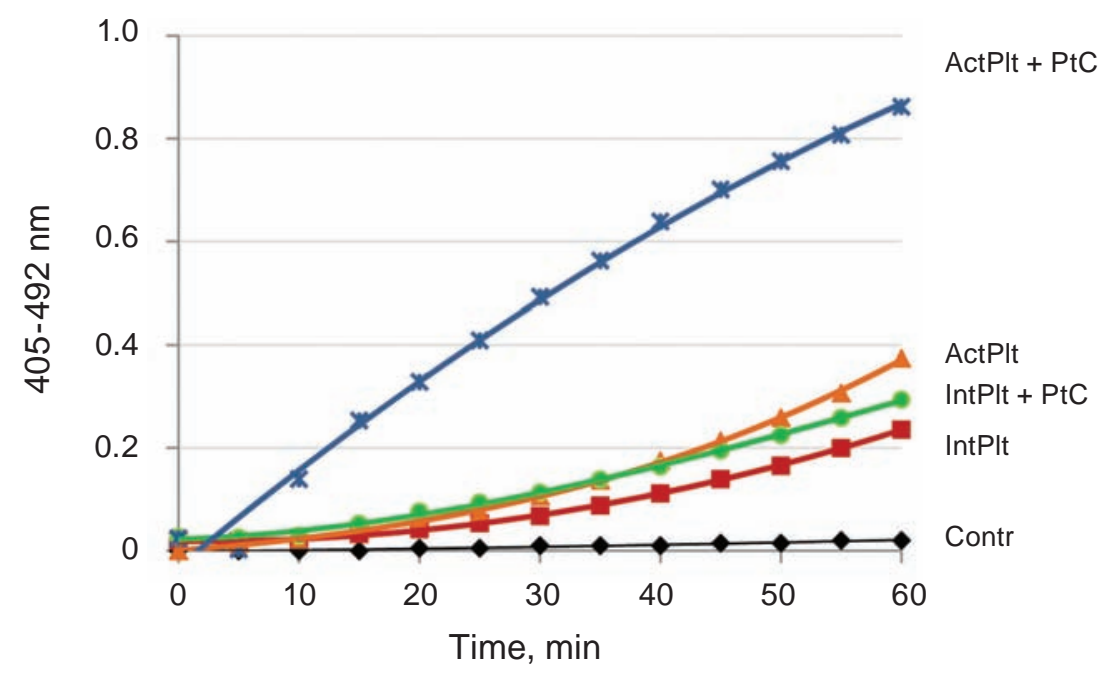

Fig. 8. Kinetics of Glu-plasminogen activation by tissue plasminogen activator on the surface of intact (IntPlt) and thrombin-activated (ActPlt) platelets without and in the presence of prothrombin complex (PtC). The kinetic curve of Glu-plasminogen activation by tissue plasminogen activator without platelets is shown as a control 


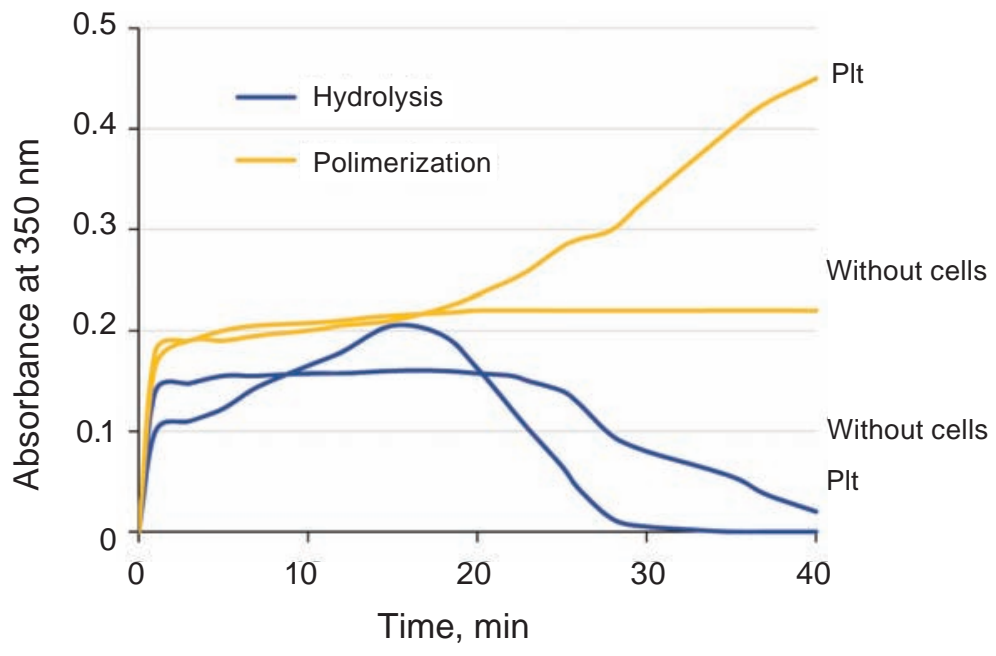

Fig. 9. Platelets' impact on polymerization and hydrolysis of desAB-fibrin by Glu-plasminogen, activated by tissue plasminogen activator. Kinetic curves of desAB-fibrin polymerization and hydrolysis without cells were taken as a control

onset time by 10 min on average $(13.3 \pm 3.4 \mathrm{~min}$ in the presence of cells compared to $23.0 \pm 4.2 \mathrm{~min}$ in control) and by increase in maximal lysis rate (from $0.024 \pm 0.005$ to $0.029 \pm 0.009$ OD units $\cdot \mathrm{min}^{-1}$ ).

To sum up, these data of plasminogen binding on activated platelet as well as stimulation of t-PAdependent plasminogen activation by platelets to provide more efficient fibrin hydrolysis, give the evidence to suggest the following mechanism of profibrinolytic action of platelets. Plasmin formed on the surface of platelets incorporated in a fibrin network forms an area of partially hydrolyzed fibrin, which exposes numerous binding sites for plasminogen localized within the clot. At the same time, a certain amount of tissue plasminogen activator, protected from inhibitors, is retained on the surface of the activated platelets. A new wave of plasmin formation caused by contacts between fibrin-bound plasminogen and platelet-bound t-PA expands the fibrin hydrolysis front and creates the conditions for diffusion and binding of an increasing number of plasminogen proteins. The proposed mechanism underlines the important role of platelets as a matrix that not only integrates supramolecular complexes, but also modulates the efficiency of their interaction.

Obtained results also suggest that the most significant effect of platelets during the process of lysis is binding of plasminogen and its activators on their surface, acceleration of plasminogen activation process and more efficient plasmin formation and, consequently, acceleration of the onset of lysis and reduction of the clot lifetime, which is important for the regulation of physiological hemostatic balance and the prevention of pathological thrombosis.

Conflict of interest. Authors have completed the Unified Conflicts of Interest form at http://ukrbiochemjournal.org/wp-content/uploads/2018/12/ coi_disclosure.pdf and declare no conflict of interest.

\section{РЕГУЛЯЦІЯ ФІБРИНОЛІЗУ \\ ТРОМБОЦИТАМИ, ЩО МІСТЯТЬ НА СВОЇЙ ПОВЕРХНІ ПЛАЗМІНОГЕН ТА ТКАНИННИЙ АКТИВАТОР}

Т. В. Гриненко, О. І. Юсова, О. В. Ревка, I. I. Паталах, Т. А. Яиенко

\author{
Інститут біохімії ім. О. В. Палладіна \\ НАН України, Київ; \\ e-mail: sedrickedel@gmail.com
}

Тромбоцити відіграють ключову роль у гемостазі як стимулятори тромбіноутворення, як центри полімеризації фібрину та ініціатори ретракції. Менш вивченою залишається їхня здатність до модуляції розчинення згустків. Метою роботи було дослідити взаємодію плазміногену та тканинного активатора 3 нативними та активованими тромбоцитами, визначити кількість плазміну, що генерується за активації плазміногену різними активаторами в присутності тромбоцитів та їхню здатність модулювати швидкість гідролізу полімерного фібрину. У 
дослідженні було застосовано спектрометричні та імунофлуориметричні методи. Показано, що циркулюючі в крові інтактні тромбоцити несли на своїй поверхні незначну кількість плазміногену, тоді як тромбініндукована активація вела до експонування плазміногензв'язувальних сайтів на плазматичній мембрані. Активовані тромбоцити стимулювали реакцію активації плазміногену тканинним активатором, урокіназою та стрептокіназою. Виявлено, що компоненти протромбінового комплексу підсилювали активацію плазміногену тканинним активатором на поверхні активованих тромбоцитів. У модельній системі 3 використанням desAB-фібрину встановлено здатність тромбоцитів стимулювати фібриноліз. Одержані результати дозволяють зробити висновок, що регуляція фібринолізу тромбоцитами реалізується через зв'язування плазміногену та активаторів плазміногену на їхній поверхні, завдяки прискоренню генерації плазміну i, відповідно, початку лізису фібрину та зменшенню загального часу існування згустку, що є важливим для підтримання гемостатичного балансу.

К л ю чо в і с ло в а: тромбоцити, плазміноген, тканинний активатор плазміногену (t-PA), урокіназа, стрептокіназа, протромбіновий комплекс.

\section{References}

1. Heemskerk JW, Mattheij NJ, Cosemans JM. Platelet-based coagulation: different populations, different functions. J Thromb Haemost. 2013; 11(1): 2-16.

2. Whyte CS, Mitchell JL, Mutch NJ. PlateletMediated Modulation of Fibrinolysis. Semin Thromb Hemost. 2017; 43(2): 115-128.

3. Brogren H, Karlsson L, Andersson M, Wang L, Erlinge D, Jern S. Platelets synthesize large amounts of active plasminogen activator inhibitor 1. Blood. 2004; 104(13): 3943-3948.

4. Brogren H, Wallmark K, Deinum J, Karlsson L, Jern S. Platelets retain high levels of active plasminogen activator inhibitor 1. PLoS One. 2011; 6(11): e26762.

5. Mosnier LO, Buijtenhuijs P, Marx PF, Meijers JC, Bouma BN. Identification of thrombin activatable fibrinolysis inhibitor (TAFI) in human platelets. Blood. 2003; 101(12): 4844-4846.
6. Schadinger SL, Lin JH, Garand M, Boffa MB. Secretion and antifibrinolytic function of thrombin-activatable fibrinolysis inhibitor from human platelets. J Thromb Haemost. 2010; 8(11): 2523-2529.

7. Baeten KM, Richard MC, Kanse SM, Mutch NJ, Degen JL, Booth NA. Activation of singlechain urokinase-type plasminogen activator by platelet-associated plasminogen: a mechanism for stimulation of fibrinolysis by platelets. J Thromb Haemost. 2010; 8(6): 1313-1322.

8. Whyte CS, Swieringa F, Mastenbroek TG, Lionikiene AS, Lancé MD, van der Meijden PE, Heemskerk JW, Mutch NJ. Plasminogen associates with phosphatidylserine-exposing platelets and contributes to thrombus lysis under flow. Blood. 2015; 125(16): 2568-2578.

9. Nieuwenhuizen W. Fibrin-mediated plasminogen activation. Ann N Y Acad Sci. 2001; 936: 237246.

10. Stepanova VV, Tkachuk VA. Urokinase as a multidomain protein and polyfunctional cell regulator. Biochemistry (Mosc). 2002; 67(1): 127-138. (In Russian).

11. Carlin SM, Resink TJ, Tamm M, Roth M. Urokinase signal transduction and its role in cell migration. FASEB J. 2005; 19(2): 195-202.

12. Miles LA, Ginsberg MH, White JG, Plow EF. Plasminogen interacts with human platelets through two distinct mechanisms. $J$ Clin Invest. 1986; 77(6): 2001-2009.

13. Tykhomyrov AA, Zhernossekov DD, Grinenko TV. Surface-exposed actin binds plasminogen on the membrane of agonist-activated platelets: a flow cytometry study. Biopolym Cell. 2017; 33(3): 172-182.

14. Zhernosekov DD, Iusova EI, Grinenko TV. Role of plasminogen/plasmin in functional activity of blood cells. Ukr Biokhim Zhurn. 2012; 84(4): 5-19. (In Russian).

15. Horne MK 3rd, Merryman PK, Cullinane AM. Plasminogen interaction with platelets: the importance of carboxyterminal lysines. Thromb Res. 2005; 116(6): 499-507.

16. Vaughan DE, Mendelsohn ME, Declerck PJ, Van Houtte E, Collen D, Loscalzo J. Characterization of the binding of human tissue-type plasminogen activator to platelets. J Biol Chem. 1989; 264(27): 15869-15874. 
17. Park S, Harker LA, Marzec UM, Levin EG. Demonstration of single chain urokinasetype plasminogen activator on human platelet membrane. Blood. 1989; 73(6): 1421-1425.

18. Deutsch DG, MertzET. Plasminogen: purification from human plasma by affinity chromatography. Science. 1970; 170(3962): 1095-1096.

19. Panyim S, Chalkley R. High resolution acrylamide gel electrophoresis of histones. Arch Biochem Biophys. 1969; 130(1): 337-346.

20. Voss D. Barium sulphate adsorption and elution of the 'prothrombin complex' factors. Scand $J$ Clin Lab Invest. 1965; 17(Suppl 84): 119.

21. Hancock DC, O'Reilly NJ. Production of polyclonal antibodies in rabbits. Methods $\mathrm{Mol}$ Biol. 2005; 295: 27-40.

22. Gear AR, Suttitanamongkol S, Viisoreanu D, Polanowska-Grabowska RK, Raha S, Camerini D. Adenosine diphosphate strongly potentiates the ability of the chemokines MDC, TARC, and SDF-1 to stimulate platelet function. Blood. 2001; 97(4): 937-945.

23. Zhernossekov DD, Roka-Moiia YM, Tykhomyrov AO, Guzyk MM, Grinenko TV. Glu- and Lys-forms of plasminogen differentially affect phosphatidylserine exposure on the platelet surface. Ukr Biochem J. 2017; 89(Spec Iss): 102-110.

24. Miles LA, Plow EF. Binding and activation of plasminogen on the platelet surface. $J$ Biol Chem. 1985; 260(7): 4303-4311.
25. Gao SW, Morser J, McLean K, Shuman MA. Differential effect of platelets on plasminogen activation by tissue plasminogen activator, urokinase, and streptokinase. Thromb Res. 1990; 58(4): 421-433.

26. Lenich C, Liu JN, Gurewich V. Thrombin stimulation of platelets induces plasminogen activation mediated by endogenous urokinasetype plasminogen activator. Blood. 1997; 90(9): 3579-3586.

27. Pryzdial EL, Bajzár L, Nesheim ME. Prothrombinase components can accelerate tissue plasminogen activator-catalyzed plasminogen activation. J Biol Chem. 1995; 270(30): 17871-17877.

28. Pryzdial EL, Kessler GE. Autoproteolysis or plasmin-mediated cleavage of factor Xaalpha exposes a plasminogen binding site and inhibits coagulation. J Biol Chem. 1996; 271(28): 1661416620.

29. Talbot K, Meixner SC, Pryzdial EL. Enhanced fibrinolysis by proteolysed coagulation factor Xa. Biochim Biophys Acta. 2010; 1804(4): 723730.

30. Pryzdial EL, Meixner SC, Talbot K, EltringhamSmith LJ, Baylis JR, Lee FM, Kastrup CJ, Sheffield WP. Thrombolysis by chemically modified coagulation factor Xa. J Thromb Haemost. 2016; 14(9): 1844-1854. 